\title{
Anaerosporobacter mobilis gen. nov., sp. nov., isolated from forest soil
}

\author{
Hyunyoung Jeong, ${ }^{1}$ Young Woon Lim, ${ }^{2}$ Hana Yi, ${ }^{1}$ Yuji Sekiguchi, ${ }^{3}$ \\ Yoichi Kamagata $^{3}$ and Jongsik Chun ${ }^{1,2}$ \\ ${ }^{1}$ School of Biological Sciences and Institute of Microbiology, Seoul National University, \\ 56-1 Shillim-dong, Kwanak-gu, Seoul 151-742, Republic of Korea \\ ${ }^{2}$ Institute of Molecular Biology and Genetics, Seoul National University, 56-1 Shillim-dong, \\ Kwanak-gu, Seoul 151-742, Republic of Korea \\ ${ }^{3}$ Institute for Biological Resources and Functions, National Institute of Advanced Industrial Science \\ and Technology (AIST), Central 6, 1-1-1 Higashi, Tsukuba, Ibaraki 305-8566, Japan
}

Correspondence

Jongsik Chun

jchun@snu.ac.kr

\begin{abstract}
A strictly anaerobic, Gram-positive, endospore-forming bacterium, strain $\mathrm{HY}-37-4^{\top}$, was isolated from a forest-soil sample collected in Jeju, Republic of Korea. The cells were motile rods with peritrichous flagella. Strain $\mathrm{HY}-37-4^{\top}$ fermented various carbohydrates and the end products from glucose were formate, acetate and $\mathrm{H}_{2}$. The major cellular fatty acids were $\mathrm{C}_{16: 0,} \mathrm{C}_{16: 0}$ $3-\mathrm{OH}$ and iso- $\mathrm{C}_{17: 1} \mathrm{l}$ /anteiso $\mathrm{B}$. The $\mathrm{G}+\mathrm{C}$ content of the DNA was $41 \mathrm{~mol} \%$. A phylogenetic analysis based on 16S rRNA sequence data indicated that the forest isolate was most closely related to Clostridium herbivorans, Clostridium populeti, Clostridium polysaccharolyticum and Eubacterium xylanophilum, which belong to Clostridium cluster XIVa. However, the low levels of 16S rRNA gene sequence similarity (92.3-93.9\%) with respect to these taxa indicate that strain HY-37- $4^{\top}$ represents a novel species. Several phenotypic characteristics readily allowed the isolate to be distinguished from other phylogenetically related taxa. On the basis of the polyphasic evidence, strain HY-37-4 $4^{\top}$ represents a novel taxon, for which the name Anaerosporobacter mobilis gen. nov., sp. nov. is proposed. The type strain is HY-37-4 $4^{\top}\left(=\mathrm{IMSNU} 40011^{\top}=\mathrm{KCTC}\right.$ $\left.5027^{\top}=\operatorname{DSM} 15930^{\top}\right)$.
\end{abstract}

During the course of a study on the diversity of culturable, mesophilic, strictly anaerobic bacteria from natural environments in Korea, a bacterial strain, designated HY $-37-4^{\mathrm{T}}$, was isolated from a forest-soil sample collected in Jeju, Republic of Korea. In this study, we report the taxonomic characterization of this forest isolate, which is considered to be a member of the family Clostridiaceae. On the basis of the polyphasic evidence, it is proposed that this isolate be classified as a novel taxon.

Strain HY $-37-4^{\mathrm{T}}$ was isolated by using the standard dilution plating method. The organism was cultivated on a Reinforced Clostridial (RC; Difco) agar plate at $30{ }^{\circ} \mathrm{C}$ under anaerobic conditions $\left(\mathrm{N}_{2} / \mathrm{CO}_{2} / \mathrm{H}_{2} ; 90: 5: 5\right.$, by vol.) and maintained as glycerol suspensions $(20 \%$, w/v) at $-80{ }^{\circ} \mathrm{C}$.

Bacterial DNA preparation, and PCR amplification and sequencing of $16 \mathrm{~S}$ rRNA gene were carried out as described previously (Chun \& Goodfellow, 1995). The sequence of the isolate was aligned manually against sequences of clostridial species obtained from the GenBank database.

The GenBank/EMBL/DDBJ accession number for the 16S rRNA gene sequence of strain $\mathrm{HY}-37-4^{\top}$ is $\mathrm{AY} 534872$.
Phylogenetic analysis was performed by using the neighbourjoining method (Saitou \& Nei, 1987). Evolutionary distance matrices were generated according to Jukes \& Cantor (1969). The resultant tree topology was evaluated in bootstrap analyses (Felsenstein, 1985) based on 1000 resamplings. Alignment and phylogenetic analyses were carried out using the jPHYDIT program (available at http://chunlab.snu.ac.kr/ jphydit/) and PAUP, version 4.0 (Swofford, 1998), as described previously (Yi \& Chun, 2006).

An almost-complete $16 \mathrm{~S}$ rRNA gene sequence (1390 bp) of the isolate was obtained and used for the initial BLAST search against the GenBank database. On the basis of $16 \mathrm{~S}$ rRNA gene sequence similarity, the closest bacterial relatives were Clostridium herbivorans (93.9\%), Clostridium populeti (93.3\%), Clostridium polysaccharolyticum (92.6\%) and Eubacterium xylanophilum (92.3\%); all belong to Clostridium cluster XIVa, defined by Collins et al. (1994). A phylogenetic tree (Fig. 1) based on the neighbour-joining method not only confirmed that our isolate is a member of cluster XIVa but also showed that it represents a distinct phyletic line; this conclusion was also supported by bootstrap analysis and the remaining two tree-making algorithms. It is evident that our isolate is not associated with 


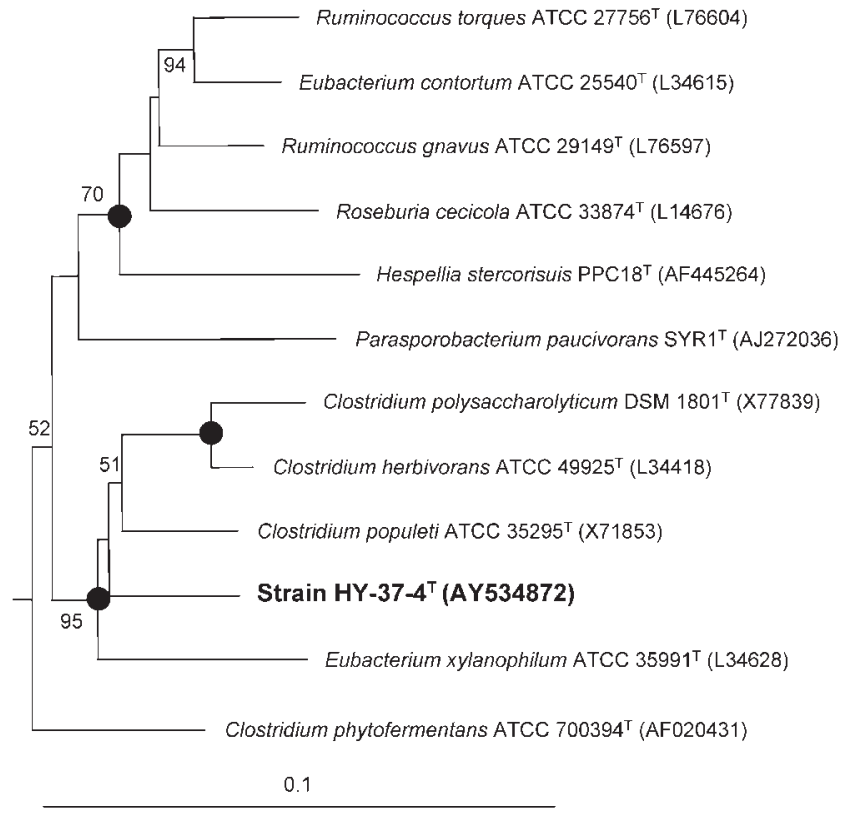

Fig. 1. Neighbour-joining phylogenetic tree, based on $16 \mathrm{~S}$ rRNA gene sequences, for strain $\mathrm{HY}-37-4^{\top}$ and closely related taxa within cluster XIVa of the Clostridium subphylum of low-G $+\mathrm{C}$, Gram-positive bacteria. Numbers at the nodes indicate percentages of 1000 bootstrap resamplings; only values $>50 \%$ are shown. Filled circles indicate that the corresponding nodes (groupings) were recovered using more than three tree-inferring methods. Clostridium perfringens ATCC $13124^{\top}$ (M59103) was used as an outgroup (not shown). Bar, 0.1 nt substitutions per position.

the type species of the genus Clostridium, Clostridium butyricum.

The 16S rRNA gene-based phylogenetic study of Collins et al. (1994) and subsequent studies (Rainey \& Stackebrandt, 1993; Stackebrandt et al., 1999) demonstrated that the known members of the genus Clostridium are polyphetic, and more than half of the species are actually not closely related to the type species, C. butyricum; the problem arises mainly from the lack of taxonomic characteristics suitable for describing a novel genus comprising endospore-forming, strictly anaerobic bacteria. On the basis of the low levels of 16S rRNA gene sequence similarity with respect to related taxa and the topologies of the phylogenetic trees, it is reasonable to conclude that strain HY-37- $4^{\mathrm{T}}$ represents a novel genus rather than a novel species of the genus Clostridium.

Gram-staining and $\mathrm{KOH}$ tests were carried out according to Johnson et al. (1995) and Powers (1995), respectively. Cell morphology was observed with cells grown on an RC agar plate at $30{ }^{\circ} \mathrm{C}$ for $72 \mathrm{~h}$, using light and scanning electron microscopy. Endospores were stained negatively by using the method of Cappuccino \& Sherman (1992) and were observed using light microscopy. Motility was checked in a Hungate tube (Bellco) containing RC semi-solid medium and motility semi-solid medium (containing, 1 distilled water ${ }^{-1}, 5.0 \mathrm{~g}$ tryptose, $5.0 \mathrm{~g} \mathrm{NaCl}$ and $5.0 \mathrm{~g}$ agar). The flagellar type was determined by transmission electron microscopy of cells stained negatively with $2 \%$ $(\mathrm{w} / \mathrm{v})$ uranyl acetate. Hydrogen peroxide $(3 \%$, v/v) was used to test for catalase activity. Strain HY $-37-4^{\mathrm{T}}$ was tested to determine growth ranges with respect to temperature (between 5 and $50{ }^{\circ} \mathrm{C}$; increments of $5{ }^{\circ} \mathrm{C}$ ), $\mathrm{pH}$ (between $\mathrm{pH} 5.0$ and 9.5; increments of $0.5 \mathrm{pH}$ units) and $\mathrm{NaCl}$ concentration (between 0 and $4.5 \%, \mathrm{w} / \mathrm{v}$; increments of $0.5 \%)$; basal medium with $1 \%(\mathrm{w} / \mathrm{v})$ glucose, as described by Mechichi et al. (1999), was used.

Substrate-utilization tests were carried out at $30{ }^{\circ} \mathrm{C}$ and an initial pH of 7.0, using the basal medium of Mechichi et al. (1999), MI medium (Warnick et al., 2002) and the commercially available API 20A system (bioMérieux). The substrates tested were L-arabinose, D-cellobiose, cellulose, D-fructose, D-galactose, D-glucose, lactose, maltose, D-mannose, D-raffinose, starch, sucrose, xylan, D-xylose, glycerol, D-mannitol, rhamnose, D-ribose, D-sorbitol, trehalose, peptone $(0.1 \%, \mathrm{w} / \mathrm{v})$ and yeast extract. All substrates were examined at a final concentration of $0.2 \%$, with the exception of peptone $(0.1 \%, \mathrm{w} / \mathrm{v})$, xylan $(1 \%, \mathrm{w} / \mathrm{v})$ and cellulose $(1 \%, w / v)$. The utilization of xylan (from larchwood; Sigma) and cellulose (microcrystalline powder; Aldrich) was determined using an agar-plate method with $1.5 \%$ agar. The results were recorded after 2 weeks incubation in the basal medium and MI medium, and within $48 \mathrm{~h}$ for the API 20A system. The API 20A system was also used to determine indole production and hydrolysis of urea, gelatin and aesculin. The end products of glucose fermentation were analysed using the method described by Jeong et al. (2004).

For the determination of the $\mathrm{G}+\mathrm{C}$ content, DNA was extracted and purified according to the method described previously (Wolff \& Gemmill, 1997). The G + C content (mol\%) of the DNA was determined using HPLC of the deoxyribonucleosides, as described by Mesbah et al. (1989), using a reversed-phase column (Supelcosil LC-18 S; Supelco). Fatty acid methyl ester analysis was performed by GLC according to the instructions of the Microbial Identification System (MIDI).

Strain HY-37-4 ${ }^{\mathrm{T}}$ was $\mathrm{KOH}$-negative and stained Grampositive. No growth occurred under aerobic conditions. Endospore formation was observed at the mid-exponential phase of growth in a liquid culture of the basal medium containing glucose. The spores were terminal and were oblong to oval in shape. Cell motility was observed, and transmission electron microscopy revealed the presence of peritrichous flagella. The cells grew at $15-40{ }^{\circ} \mathrm{C}$ (optimum, $30{ }^{\circ} \mathrm{C}$ ), at $\mathrm{pH}$ 5.5-9.0 (optimum, $\mathrm{pH} 6.5-7.0$ ) and at $\mathrm{NaCl}$ concentrations of $0-3.0 \%(\mathrm{w} / \mathrm{v})$ (optimum, $0.5 \%$ ). The substrate-utilization patterns obtained in tests using basal medium, MI medium and the API 20A system were identical: the details are presented in the genus and species descriptions. With $20 \mathrm{mM}$ glucose as the sole carbon 
source, the isolate produced formate $\left(1.21 \mathrm{mmol} \mathrm{l}^{-1}\right)$, acetate $\left(2.42 \mathrm{mmol} \mathrm{l}^{-1}\right)$ and hydrogen $\left(5.44 \mathrm{mmol} \mathrm{l}^{-1}\right)$ as the major fermentation products; with $20 \mathrm{mM}$ glucose supplemented with $0.1 \%$ yeast extract, it produced formate $\left(5.55 \mathrm{mmol} \mathrm{l}^{-1}\right)$, acetate $\left(4.07 \mathrm{mmol} \mathrm{l}^{-1}\right)$ and hydrogen $\left(6.36 \mathrm{mmol} \mathrm{l}^{-1}\right)$. The DNA G $+\mathrm{C}$ content of strain HY-37$4^{\mathrm{T}}$ was $41 \mathrm{~mol} \%$. The cellular fatty acid profile consisted of $\mathrm{C}_{16: 0}(24.0 \%), \mathrm{C}_{16: 0} 3-\mathrm{OH}(21.8 \%)$, iso- $\mathrm{C}_{17: 1} \mathrm{I} /$ anteiso $\mathrm{B}$ $(11.9 \%), \mathrm{C}_{18: 1} \omega 7 c(7.8 \%), \mathrm{C}_{16: 1} \omega 7 c$ and/or iso- $\mathrm{C}_{15: 0}$ $2-\mathrm{OH}(6.5 \%), \mathrm{C}_{16: 1} \omega 9 c(4.1 \%), \mathrm{C}_{18: 1} \omega 9 c(4.0 \%)$, an unknown fatty acid (equivalent chain-length, 14.959) (3.8\%), 10 methyl- $\mathrm{C}_{19: 0}(3.4 \%), \mathrm{C}_{13: 1}$ AT 12-13 (2.7\%), $\mathrm{C}_{14: 0} 3-\mathrm{OH}$ and/or $\mathrm{C}_{16: 1}$ iso I $(2.7 \%), \mathrm{C}_{14: 0}(1.8 \%)$, and $\mathrm{C}_{15: 1}$ iso $\mathrm{H}$ and/or $\mathrm{C}_{13: 0} 3-\mathrm{OH}(1.6 \%)$. Several phenotypic properties that serve to differentiate strain $\mathrm{HY}-37-4^{\mathrm{T}}$ from phylogenetically related bacteria have been determined (see Table 1).

On the basis of the polyphasic evidence presented here, strain HY-37-4 $4^{\mathrm{T}}$ should be classified as representing a novel genus and species, for which we propose the name Anaerosporobacter mobilis gen. nov., sp. nov.

\section{Description of Anaerosporobacter gen. nov.}

Anaerosporobacter (An.a.e.ro.spo.ro.bac'ter. Gr. pref. anwithout; Gr. n. aer air; Gr. n. spora a seed, and, in biology, a spore; N.L. masc. n. bacter a rod; N.L. masc. n. Anaerosporobacter an anaerobic, spore-forming, rod-shaped bacterium).
Gram-positive, endospore-forming, strictly anaerobic, mesophilic and neutrophilic rods. Motile by means of peritrichous flagella. Produces almost oval terminal endospores. Various sugars, including glucose, are fermented. The major end products from glucose are formate, acetate and $\mathrm{H}_{2}$. Catalase- and urease-negative. Indole is not produced. Aesculin is hydrolysed, but gelatin is not.

The type species is Anaerosporobacter mobilis. Phylogenetically, the genus is a member of the XIVa cluster of the low-G + C Clostridiales group (Collins et al., 1994).

\section{Description of Anaerosporobacter mobilis sp. nov.}

Anaerosporobacter mobilis (mo.bi'lis. L. masc. adj., mobilis motile).

Cells are $0.5-0.6 \mu \mathrm{m}$ in width by $2.3-5.5 \mu \mathrm{m}$ in length. Colonies on RC agar plates are approximately $1.0-2.0 \mathrm{~mm}$ in diameter, circular with erose edges, convex, translucent to opaque, greyish-white in colour and slightly smooth after $72 \mathrm{~h}$. Grows optimally at $30^{\circ} \mathrm{C}$ and $\mathrm{pH}$ 6.5-7.0; the optimal $\mathrm{NaCl}$ concentration is $0.5 \%(\mathrm{w} / \mathrm{v})$. Utilizes a wide range of saccharides as substrates, including L-arabinose, D-cellobiose, cellulose, D-fructose, D-galactose, D-glucose, lactose, maltose, D-mannose, D-raffinose, salicin, starch, sucrose, xylan and D-xylose, but does not produce acid from glycerol, D-mannitol, melezitose, rhamnose, D-ribose, D-sorbitol, trehalose, peptone $(0.1 \%, w / v)$ or yeast extract

Table 1. Characteristics that differentiate strain $\mathrm{HY}-37-4^{\top}$ from its nearest phylogenetic relatives

Strains: 1, HY-37-4 ${ }^{\mathrm{T}}$; 2, Clostridium herbivorans ATCC $49925^{\mathrm{T}}$; 3, Clostridium phytofermentans ATCC $700394^{\mathrm{T}}$; 4, Eubacterium xylanophilum ATCC $35991^{\mathrm{T}}$; 5, Ruminococcus gnavus ATCC $29149^{\mathrm{T}}$; 6, Roseburia cecicola ATCC $33874^{\mathrm{T}}$. All strains are members of Clostridium cluster XIVa as defined by Collins et al. (1994). Symbols: +, positive; -, negative; w, weakly positive; ND, not determined. Data from Varel et al. (1995), Warnick et al. (2002), van Gylswyk \& van der Toorn (1985), Moore et al. (1976) and Stanton \& Savage (1983) and this study.

\begin{tabular}{|c|c|c|c|c|c|c|}
\hline Characteristic & 1 & 2 & 3 & 4 & 5 & 6 \\
\hline Gram stain & + & + & - & + & + & - \\
\hline Cell shape & Rod & Rod & Rod & Coccoid rod & Coccus & Rod \\
\hline Sporulation & + & + & + & - & - & - \\
\hline Motility & + & + & + & + & - & + \\
\hline DNA G + C content $(\mathrm{mol} \%)$ & 41 & 38 & 36 & 39 & 43 & 42 \\
\hline Optimum growth temperature $\left({ }^{\circ} \mathrm{C}\right)$ & 30 & $39-42$ & 37 & $\mathrm{ND}$ & 37 & 37 \\
\hline Aesculin hydrolysis & + & - & - & - & + & - \\
\hline \multicolumn{7}{|l|}{ Utilization of: } \\
\hline L-Arabinose & + & - & $\mathrm{w}$ & - & + & ND \\
\hline D-Cellobiose & + & + & + & + & - & + \\
\hline D-Fructose & + & - & $\mathrm{w}$ & - & + & - \\
\hline D-Galactose & + & - & + & - & + & + \\
\hline D-Glucose & + & - & + & - & + & + \\
\hline Lactose & + & - & + & - & - & - \\
\hline Maltose & + & + & + & - & + & + \\
\hline D-Mannose & + & - & + & - & - & $\mathrm{ND}$ \\
\hline D-Raffinose & + & - & $\mathrm{ND}$ & - & + & + \\
\hline Sucrose & + & - & - & - & + & + \\
\hline D-Xylose & + & - & + & - & + & + \\
\hline
\end{tabular}


$(0.2 \%, w / v)$. The major cellular fatty acids are $\mathrm{C}_{16: 0}, \mathrm{C}_{16: 0}$ $3-\mathrm{OH}$ and iso- $\mathrm{C}_{17: 1} \mathrm{I} /$ anteiso $\mathrm{B}$. The $\mathrm{G}+\mathrm{C}$ content of the DNA of the type strain is $41 \mathrm{~mol} \%$.

The type strain, HY-37-4 ${ }^{\mathrm{T}} \quad\left(=\mathrm{IMSNU} \quad 40011^{\mathrm{T}}=\mathrm{KCTC}\right.$ $5027^{\mathrm{T}}=\mathrm{DSM} 15930^{\mathrm{T}}$ ), was isolated from a forest-soil sample from Jeju, Republic of Korea.

\section{Acknowledgements}

We thank Mizuho Muramatsu (National Institute of Advanced Industrial Science and Technology, Japan) and Hang-Yeon Weon (Rural Development Association, Republic of Korea) for technical assistance. We are grateful to J. P. Euzéby for help with the Latin nomenclature. This work was supported by the 21C Frontier Microbial Genomics and Applications Center Program and the Korea Science and Engineering Foundation through the National Research Laboratory Program funded by the Ministry of Science and Technology (no. M10500000110-06J0000-11010).

\section{References}

Cappuccino, J. C. \& Sherman, N. (1992). Negative staining. In Microbiology: a Laboratory Manual, 3rd edn, pp. 27-28. Edited by J. C. Cappuccino \& N. Sherman. Redwood City, CA: Benjamin/Cummings.

Chun, J. \& Goodfellow, M. (1995). A phylogenetic analysis of the genus Nocardia with $16 \mathrm{~S}$ rRNA gene sequences. Int J Syst Bacteriol 45, 240-245.

Collins, M. D., Lawson, P. A., Willems, A., Cordoba, J. J., FernandezGarayzabal, J., Garcia, P., Cai, J., Hippe, H. \& Farrow, J. A. (1994). The phylogeny of the genus Clostridium: proposal of five new genera and eleven new species combinations. Int J Syst Bacteriol 44, 812-826.

Felsenstein, J. (1985). Confidence limits on phylogenies: an approach using the bootstrap. Evolution 39, 783-791.

Jeong, H., Yi, H., Sekiguchi, Y., Muramatsu, M., Kamagata, Y. \& Chun, J. (2004). Clostridium jejuense sp. nov., isolated from soil. Int $J$ Syst Evol Microbiol 54, 1465-1468.

Johnson, M. J., Thatcher, E. \& Cox, M. E. (1995). Techniques for controlling variability in gram staining of obligate anaerobes. J Clin Microbiol 33, 755-758.

Jukes, T. H. \& Cantor, C. R. (1969). Evolution of protein molecules. In Mammalian Protein Metabolism, pp. 21-132. Edited by H. N. Munro. New York: Academic Press.
Mechichi, T., Labat, M., Garcia, J. L., Thomas, P. \& Patel, B. K. C. (1999). Characterization of a new xylanolytic bacterium, Clostridium xylanovorans sp. nov. Syst Appl Microbiol 22, 366-371.

Mesbah, M., Premachandran, U. \& Whitman, W. B. (1989). Precise measurement of the $\mathrm{G}+\mathrm{C}$ content of deoxyribonucleic acid by highperformance liquid chromatography. Int J Syst Bacteriol 39, 159-167.

Moore, W. E. C., Johnson, J. L. \& Holdeman, L. V. (1976). Emendation of Bacteroidaceae and Butyrivibrio and descriptions of Desulfomonas gen. nov. and ten new species in the genera Desulfomonas, Butyrivibrio, Eubacterium, Clostridium, and Ruminococcus. Int J Syst Bacteriol 26, 238-252.

Powers, E. M. (1995). Efficacy of the Ryu nonstaining $\mathrm{KOH}$ technique for rapidly determining gram reactions of food-borne and waterborne bacteria and yeasts. Appl Environ Microbiol 61, 3756-3758.

Rainey, F. A. \& Stackebrandt, E. (1993). 16S rRNA analysis reveals phylogenetic diversity among the polysaccharolytic clostridia. FEMS Microbiol Lett 113, 125-128.

Saitou, N. \& Nei, M. (1987). The neighbor-joining method: a new method for reconstructing phylogenetic trees. Mol Biol Evol 4, 406-425.

Stackebrandt, E., Kramer, I., Swiderski, J. \& Hippe, H. (1999). Phylogenetic basis for a taxonomic dissection of the genus Clostridium. FEMS Immunol Med Microbiol 24, 253-258.

Stanton, T. B. \& Savage, D. C. (1983). Roseburia cecicola gen. nov., sp. nov., a motile, obligately anaerobic bacterium from a mouse cecum. Int J Syst Bacteriol 33, 618-627.

Swofford, D. L. (1998). Phylogenetic analysis using parsimony (PAUP). Version 4. Sunderland, MA: Sinauer Associates.

van Gylswyk, N. O. \& van der Toorn, J. J. T. K. (1985). Eubacterium uniforme sp. nov. and Eubacterium xylanophilum sp. nov., fiberdigesting bacteria from the rumina of sheep fed corn stover. Int J Syst Bacteriol 35, 323-326.

Varel, V. H., Tanner, R. S. \& Woese, C. R. (1995). Clostridium herbivorans sp. nov., a cellulolytic anaerobe from the pig intestine. Int J Syst Bacteriol 45, 490-494.

Warnick, T. A., Methe, B. A. \& Leschine, S. B. (2002). Clostridium phytofermentans sp. nov., a cellulolytic mesophile from forest soil. Int J Syst Evol Microbiol 52, 1155-1160.

Wolff, R. \& Gemmill, R. (1997). Purifying and analyzing genomic DNA. In Genomic Analysis: a Laboratory Manual. Edited by E. D. Green, B. Birren, S. Klapholz, R. M. Myers \& P. Hieter. Cold Spring Harbor, NY: Cold Spring Harbor Laboratory Press.

Yi, H. \& Chun, J. (2006). Thalassobius aestuarii sp. nov., isolated from tidal flat sediment. J Microbiol 44, 171-176. 